\title{
The Middle Palaeolithic of the Nejd, Saudi Arabia
}

Huw S. Groucutt ${ }^{1 *}$, Paul Breeze ${ }^{2}$, Nick A. Drake ${ }^{2}$, Richard Jennings ${ }^{1}$, Ash Parton ${ }^{1,3}$, Tom White $^{1}$, Ceri Shipton ${ }^{4}$, Laine Clark-Balzan ${ }^{5}$, Abdulaziz Al-Omari ${ }^{6}$, Patrick Cuthbertson ${ }^{1}$, Oshan M. C. Wedage ${ }^{7}$, Marco A. Bernal ${ }^{1}$, Abdullah Alsharekh $^{8}$, Michael D. Petraglia ${ }^{1}$

${ }^{1}$ University of Oxford, Oxford, U.K., ${ }^{2}$ King's College London, London, U.K., ${ }^{3}$ Oxford Brookes University, Oxford, U.K., ${ }^{4}$ University of Cambridge, Cambridge, U.K., ${ }^{5}$ University of Freiberg, Freiberg, Germany, ${ }^{6}$ Saudi Commission for Tourism and National Heritage, Riyadh, Saudi Arabia, ${ }^{7}$ Department of Archaeological Survey of Sri Lanka, Colombo, Sri Lanka, ${ }^{8}$ King Saud University, Riyadh, Saudi Arabia

Correspondence to: Huw S. Groucutt, Research Laboratory for Archaeology and the History of Art, School of Archaeology, Hayes House, 75 George Street, Oxford, OX1 2BQ, U.K., Email: huw.groucutt@ rlaha.ox.ac.uk 
The Pleistocene archaeological record of the Arabian Peninsula is increasingly recognized as being of great importance for resolving some of the major debates in hominin evolutionary studies. Though there has been an acceleration in the rate of fieldwork and discovery of archaeological sites in recent years, little is known about hominin occupations in the Pleistocene over vast areas of Arabia. Here we report on the identification of five new Middle Palaeolithic sites from the Nejd of central Arabia and the southern margins of the Nefud Desert to the north. The importance of these sites centers on their diversity in terms of landscape positions, raw materials used for lithic manufacture, and core reduction methods. Our findings indicate multiple hominin dispersals into Arabia and complex subsequent patterns of behavior and demography.

\section{Keywords}

Saudi Arabia, Middle Palaeolithic, lithics, Levallois, survey 


\section{Introduction}

The Arabian Peninsula is a vast area of more than 3,000,000 sq km which has seen relatively little archaeological research and interdisciplinary study, despite its considerable importance as a nexus between continents, its varied landscapes and a history of environmental fluctuation. In recent years there has been a rapid increase in the identification and analysis of Middle Palaeolithic (MP) sites in the region (e.g., Petraglia and Alsharekh 2003; Petraglia and Rose 2009; Groucutt and Petraglia 2012; Groucutt et al., 2015a; Scerri et al., 2015). This accumulating body of research is of central importance for a number of major debates in archaeology, including understanding the dispersal of Homo sapiens out of Africa (Mellars et al. 2013; Groucutt and Petraglia 2014; Groucutt et al. 2015 b), hominin adaptation to environmental fluctuation, particularly aridification and seasonality (Groucutt and Blinkhorn 2013; Jennings et al. 2015 a; Parton et al. 2015) and interactions between hominin populations.

Several recent archaeological advances have focused on eastern and southern Arabia. In the United Arab Emirates, the site of Jebel Faya revealed a series of buried assemblages covering much of the Late Pleistocene (Armitage et al. 2011; Bretzke et al. 2014). The discoverers argued that the character of the oldest Assemblage $\mathrm{C}$ suggested connections to the African Middle Stone Age, with the younger assemblages indicating autochthonous developments. In the Dhofar region of Oman a large number of assemblages have been identified which share some similarities with "Nubian Complex" assemblages, previously best known from northeastern Africa (Rose et al. 2011; Usik et al. 2013). In the Huqf region of Oman, a few hundred kilometers east of Dhofar, extensive and systematic survey has found no evidence for Nubian (“beaked”) Levallois technology (Jagher 2009; Jagher et al. 2011), revealing the considerable spatial variability in the Palaeolithic record of Arabia. In Yemen, stratified and well-dated MP sites were discovered in Wadi Surdud (Delagnes et al. 2012, 
2013). The technology there, most clearly understood from the site of Shi'bat Dihya 1 (SD-1), is essentially non-Levallois in its characteristics, and focuses on the production of blades and points from single platform cores (although a small number of cores and flakes are described as being "Levallois-like"). The lithic assemblages from Wadi Surdud are unlike those from surrounding regions, and as such, have been interpreted by the discoverers as indicating another autochthonous development, in a refugium.

These findings in southern and eastern Arabia have finally ended the status of the region as a terra incognita. However, if the objective is to understand factors such as dispersal from Africa and the Levant, we need to study sites closer to those regions than the southern and eastern margins of Arabia. The distinctively local character of Assemblages A and B of Jebel Faya and of Shi'bat Dihya 1 lack self-evident cultural ancestry and therefore offer limited obvious insights into dispersal processes.

Central and northern Arabia are therefore both critical areas in understanding behavioral and demographic variability across the peninsula, and how this relates to factors such as population dispersal. This region is a connection between the Levant to the northand through it the only land route out of Africa — and southern Arabia. The "Comprehensive Survey of the Kingdom" (1976-1981) revealed a large number of MP sites in the study area, but these were not followed up with detailed interdisciplinary studies. Aside from recent findings (FIG. 1K, L) near Al Kharj (Crassard and Hilbert 2013) and the discovery of several MP assemblages (FIG. 1A-J) at Jubbah (Petraglia et al. 2011, 2012; Groucutt et al. 2015 a) very little is known of the MP of central and northern Arabia.

Here we introduce five new MP sites that we identified during recent surveys. The study area is the Nejd (alternatively transliterated as Najd), the plateau of central Saudi Arabia. This can be defined as the area north of the Empty Quarter (Rub' al Khali) desert, east 
of the Hijaz (the highland belt of western Arabia), south of the sand sea of the Nefud desert, and broadly west of the Ad-Dahna desert. Below we focus on understanding the range of Middle Palaeolithic variability observed, rather than the precise spatial and temporal parameters of that variability. To this end, our study provides a foundation for future research, and particularly the discovery of stratified archaeological assemblages which can be dated and placed into environmental contexts.

\section{Previous research on the Middle Palaeolithic of the Nejd}

The Comprehensive Survey of the Kingdom resulted in the first identification of MP sites on the Nejd and its fringes (Petraglia and Alsharekh 2003; Groucutt and Petraglia 2012). These surveys discovered a large number of Middle Palaeolithic sites, and this cultural phase was often the most well represented Palaeolithic period. Most of these sites were described as "Mousterian," and their cultural affiliation defined primarily in relation to the Levant.

Parr and colleagues (1978) first reported MP sites in the northern part of the Nejd. Zarins and colleagues (1979) then described a number of MP sites in the area. Knappers there mostly used what is described as ferruginous sandstone, although chert and quartzite are also represented in smaller numbers. Zarins and colleagues (1979) commented that the 'discoidal core with flat back' is the most common core type they encountered. From their illustrations it is clear that most of these, as a result of recent changes in understandings of Levallois technology (Boëda 1995), would today be defined as recurrent centripetal Levallois cores. Other types of cores, including discoidal, single platform and one Nubian Levallois-like core, as well as a diversity of other lithic artifacts, were also found at these sites.

Zarins and colleagues (1980) reported 25 MP sites from the Nejd, with quartzite being the main raw material, but andesite, rhyolite and chert were also represented. They describe two of the sites as belonging to the Mousterian of Acheulean Tradition defined on the grounds 
of technology and patination. It is possible that certain MP assemblages in this area contain a bifacial component, but it is also possible that these assemblages are palimpsests of different time periods. Zarins and colleagues (1982) report MP sites in the environs of Riyadh, composed of quartzite raw material sources, chert lithics associated with palaeolake shorelines, and small scatters atop plateaus. Little information is given on the technology of these sites, aside from some photographs of flakes and blades.

To the north, survey in the Jubbah basin in the Nefud desert revealed three MP sites near a palaeolake, as well as important environmental records (Garrard et al. 1981). More recent research has greatly added to knowledge of the MP at the Jubbah Oasis (Petraglia et al. 2011; 2012; Groucutt et al. 2015 a). Several sites have produced stratified Middle Palaeolithic assemblages in association with evidence for more humid climatic conditions: Jebel Qatar-1 (JQ-1), Jebel Umm Sanman-1 (JSM-1), and Jebel Katefeh-1 (JKF-1), as well as a number of surface sites. Here our aim is to highlight the technological characteristics and diversity of the MP at Jubbah. This diversity likely reflects several factors, including chronological differences, raw material variability, differences in site function and putatively cultural variation.

JQ-1 preserves a sedimentary record from at least MIS 7 to late MIS 5 and consists of a stratified sequence of lacustrine, calcrete and archaeological deposits. Within this timeframe at least two periods of MP occupation occurred (Petraglia et al. 2011, 2012). The older MP assemblage dates to at least MIS 7. It consists of a small assemblage of quartzite, chert, and rhyolite flakes. At least one of the flakes is a preferential Levallois flake. The younger Middle Palaeolithic assemblage ( $75 \mathrm{kya}$ ) is dominated by quartzite, but rhyolite and chert are present in small numbers. The assemblage features recurrent centripetal Levallois (FIG. 1:I.) and discoidal cores, while the presence of preferential Levallois flakes shows an earlier phase of core reduction. Side retouched flakes (FIG. 1H, J) and a retouched point are present. 
JSM-1 is located on the southern margin of the largest jebel (hill) in the Jubbah area. Lithic material was both collected on the surface and from trenches. OSL samples produced a wide range of results, indicating an early to mid-Late Pleistocene age for the assemblage. Most of the debitage at JSM-1 is small and fragmentary, and few retouched tools are present. Cores are dominated by Levallois types, with both centripetally prepared preferential (e.g. FIG. 1E, G) and recurrent centripetal techniques present.

JKF-1 was identified beside a small palaeolake basin southwest of the main Jubbah basin (Groucutt et al. 2015 a). The assemblage $(\mathrm{n}=1222)$ is made of a mix of quartzite, presumed to be sourced from the site of JKF-12 a few hundred meters west, and quartz, which is abundantly present in the basin. The site is dated by OSL to $90-50 \mathrm{kya}$. Bioturbation was observed which was interpreted by Petraglia et al. (2012) as indicating the intrusion of younger grains ( $\sim 50 \mathrm{kya})$ into an older deposit containing the archaeological horizon ( 90 kya). Lithics at the site come from a single buried horizon and from the surface, where they have clearly eroded from this layer. The cores and flakes demonstrate predominantly unidirectional reduction. Refitting studies are needed to confirm the extent to which this primarily unidirectional removal of Levallois products was preferential or recurrent. In the earlier phases, reduction appears to have been unidirectional Levallois in character, progressing to unidirectional-convergent and the production of some fine Levallois points (FIG. 1A-C), before, in many examples, then being reduced centripetally. Quartz was reduced from simple single platform cores, which in some cases continued to be reduced in a Levallois-like manner, sometimes producing predetermined flakes (FIG. 1, D). Retouched flakes are rare at the site $(n=10)$, with the small number present mostly consisting of side retouched flakes.

*figure 1 hereabouts* 
Finally in terms of background, Crassard and Hilbert (2013) and Schiettecatte and colleagues (2013) reported the discovery of surface MP sites near Al-Kharj. These are predominantly of quartzite and silicified sandstone, with most sites directly associated with raw material sources. The key site is that of AK-22, where a scatter of quartzite lithics covering ca. $60 \times 20 \mathrm{~m}$ was identified. A selective sample of "diagnostic" elements was made, focusing on cores. Of the cores collected, various types are present including single platform, bidirectional, preferential Levallois with centripetal preparation and recurrent centripetal Levallois. Crassard and Hilbert (2013) highlight the importance of cores that share similarities with 'Nubian Levallois' cores, best known from northeast Africa and southern Arabia. These cores make up $13 \%$ of the cores in their selective sample. To Crassard and Hilbert (2013) these cores (FIG. 1L) provide possible evidence for the dispersal of a human population out of Africa into Arabia in the Late Pleistocene (but see Groucutt et al., 2015 ,b c).

\section{Methods}

The MP sites reported here were identified during two seasons of survey in 2013 and 2014. Areas of interest were identified by the analysis of satellite imagery and geological maps, as well as the use of remote sensing techniques. Regional palaeodrainage systems were mapped through analysis of SRTM hydrological data (the HydroSHEDS dataset)(Lehner et al. 2008), with a series of flow accumulation thresholds defined to extract relict surface and buried shallow sub-surface drainage features (Breeze et al. 2015). HydroSHEDS data and comparable SRTM hydrology data, have previously been applied to arid region palaeodrainage mapping in the Sahara (Ghoneim and El-Baz 2007a; 2007b), and in the Nefud and Rub' al Khali regions of Saudi Arabia (Crassard et al. 2013a, 2013b; Petraglia et al. 2012). Potential regional sedimentary archives, such as palaeolake deposits, were also identified, through examination of published geological maps (Delfour et al. 1984; Roobol 
and Camp 1991) coupled with examination of optical remotely sensed data and multispectral classification of Landsat data (Breeze et al. 2015). The sites in the northern part of the Nejd discussed here are all situated in areas identified as being of palaeohydrological importance. These took the form of basins and alluvial fans (Al Qana area) and the area connecting two of the major palaeoriver systems, Wadi al-Hamd flowing to the west and Wadi al-Batin flowing to the east (the Shuwaymis area). In the Dawadmi area, survey targeted dykes and other raw material sources as the likely locations of sites, as well as wadis.

In the field, systematic pedestrian survey was conducted in the areas in proximity to raw material sources and/or areas of palaeohydrological significance. Archaeological findings of all time periods were recorded although here we focus only on the Middle Palaeolithic.

All of the sites identified during the survey are surface occurrences. Given the dominant aridity of the area it is likely that occupations were limited to occasional humid periods. The aim here is to introduce and discuss the range of raw materials used and technologies found in the study area. The sites discussed here each appear broadly homogenous in terms of technological patterns and weathering, although their temporal homogeneity must remain a hypothesis.

Initial analyses of the assemblages were carried out in the field. Representative samples were collected for more detailed analysis. The lithic analyses focused on descriptions of the major reduction methods present, as well as on any specific morpho-technological features. A common feature at several of the sites was the rarity of both retouched artifacts and often of clearly preferential flakes, suggesting that these were sites where raw material procurement and early stage reduction took place. The assemblages are dominated by a combination of cores and rather amorphous flaking debitage. In this situation, cores are a particularly useful way to understand the reduction processes (Thompson et al. 2014), with 
the caveats that cores only reveal the terminal phase of reduction. The reconstruction of reduction methods (below) is therefore based on a combined assessment of both the cores and, where possible, the debitage. The attributes recorded follow those described in Scerri and colleagues (2014) and Groucutt and colleagues (2015 a). In brief, these consist of a variety of metric (measurements using calipers), technological (scar patterns and platform preparations) and typological (core types) attributes. Technological trends are described in terms of the articulation of these metrical, technological and typological characteristics. The hypotheses on the reconstructed reduction sequences can be tested in the future by studies of enlarged samples, the detailed analysis of debitage attributes, and by refitting studies.

\section{Results}

Five main new MP sites from the Nejd and southern margins of the Nefud desert were discovered during the surveys (FIG. 2), as well as small numbers of finds at other localities. As summarized in Table 1, these five sites occupy a diversity of landscape settings. Each site focuses on the near-exclusive use of a single raw material. There is considerable variation in both the density of lithics and in reduction methods and other features of lithic technology, which are elaborated below.

*figure 2 hereabouts*

*figure 3 hereabouts*

Al Qana-1 (QAN-1)

The site of QAN-1 is located on the outskirts of the village of Al Qana, on the southern margins of the Nefud desert (FIGS. 3A, 4). It was targeted for field survey, because a Neolithic site (205-13) had been reported from rapid survey in the 1970s (Parr et al. 1978), and because our remote sensing studies detected sediments of interest there. 
The site is located on the distal edge of an alluvial fan lobe, which extends from the mountains to the south. The QAN-1 sediments on which the lithic artifacts are found comprise coarse sands and a thin skirt of poorly sorted and moderately-well rounded fine gravels, typical low energy sheetflood deposits. These sediments extend beneath, and therefore predate, the surrounding dunes. Three small one sq $\mathrm{m}$ test trenches (FIG. 3A) failed to reveal any convincingly buried lithics.

Middle Palaeolithic artifacts were found in large numbers at the site, focused in two concentrations around 27.7665 N, 41.4115 E and 27.7665 N, 41.4125 E. Lower Palaeolithic (LP) material was found slightly to the north, as described by Shipton and colleagues (2014), beginning where a ditch and bank are present and broadly centering around $27.7675 \mathrm{~N}$, 41.412 E.

*figure 4 hereabouts*

\section{Shuwaymis $11($ SHW-11)}

Survey in the Shuwaymis area revealed relatively little MP material. Most cases consisted of single artifacts, such as a centripetally prepared preferential Levallois flake with a faceted striking platform, which was found close to the Shuwaymis 1 rock art site $(26.1554 \mathrm{~N}$, 39.8978 E). A single unidirectional-convergent Levallois point core with a faceted striking platform was also found at $26.12685 \mathrm{~N}, 40.3724 \mathrm{E}$. A greater number of lithics, but still in small frequencies and at low densities, were identified at SHW-10 (26.0875 N, 40.3822 E) and SHW-12 (26.1333 N, 40.3714 E). These have technological features similar to those at SHW-11 (below). It was only at Shuwaymis-11 that a relatively high density assemblage was located (FIGS. 3B-C, 4).

SHW-11 is located next to a river channel that is a headwater tributary of Wadi al Batin which flows from the Shuwaymis region to Kuwait. The river channel was mapped 
during the drainage analyses, and is incised into a basalt lava flow on the northern side of the site (FIG. 3B). Lithic artifacts occur in high density, scattered amongst natural rocks (FIG. 3B), over an area of approximately $60 \times 20 \mathrm{~m}$.

\section{Dawadmi-23 (DW-23)}

DWD-23 is located beside one of the numerous dykes that are present in the area (FIGS. 3F, 5). These dykes result from intrusions of more durable igneous rock exposed by subsequent erosion. Because they are harder than the surrounding bedrock, these dykes form significant linear topographic features in the landscape in areas such as Dawadmi. Some of these dykes have previously been studied primarily in terms of their LP archaeology (Petraglia et al. 2009; Jennings et al. 2015 b). Fieldwork in the area by the Palaeodeserts team in 2014 revealed a large number of archaeological sites spanning various time periods. While LP artifacts are abundant in the Dawadmi area, there seems to be a paucity of MP material. The MP sites we identified in the area comprised artifacts made on homogenous and fine grained materials in comparison to the LP sites.

DWD-23 lies around $90 \mathrm{~km}$ northwest of Dawadmi. Dykes in this vicinity, near the villages of Badayi bin Naim and Al Mushash are mapped as predominantly felsic and undifferentiated dykes (Delfour et al. 1984). Nine dykes in this area were investigated by the team, and only that at DWD-23 had lithic material. The dyke at DWD-23 is felsic with low topographic expression and a moderate degree of fracturing. Other nearby dykes were generally more fractured, producing material less suitable for lithic reduction. Lower Palaeolithic artifacts (particularly handaxes) were found at the bottom of the slope below the dyke. Higher up, and closer to the dyke itself, a low density scatter of MP artifacts was identified.

*figure 5 hereabouts* 
To the east of Dawadmi, survey was conducted along incised wadi courses mapped by the remote sensing (FIG. 5). These include the large ( 200 m wide) Wadi Fajman where, however, no lithics were identified. This is perhaps due to active slope movement, but may also reflect the limited duration of the survey. A more productive area was identified around Az Zu'aynah (AZA). The site of AZA-2 is situated at the western end of a chain of small jebels which define the northern side of a $\sim 2 \mathrm{~km}$ wide wadi (FIG. 5). The valley floor comprises a fluvial braidplain and is marked by relatively dense vegetation including trees, growing along the courses of presently active wadi channels. These modern channels are incised into older terrace deposits to a depth of approximately $1.5 \mathrm{~m}$, exposing sections of coarse, poorly-sorted, weakly bedded red sands and angular gravels deposited during earlier channel flow events. Near the base of adjacent floodplain margin bedrock outcrops, these terraces are covered with angular-to-rounded gravels and cobbles, along with colluvial material eroded and re-deposited downslope of the outcrop. The lithic materials reported here were found on the floodplain margin slopes, a few meters above and away from the present (episodic) river channel and are associated with the exposures of bedrock that formed the raw material for lithic manufacture (FIG. 3E).

\section{Jebel Abyad-1 (ABY-1)}

The final site identified in the Dawadmi area is that of ABY-1. The site consists of an isolated and highly visible hill jebel of white quartz (FIG. 5). The peak of the jebel consists of a thick plug of quartz, while the flanks are covered with pieces of quartz of various sizes eroding from this source and moving downslope (FIG. 3D). A small number of probably LP handaxes 
were found close to the jebel, but away from the area covered by quartz, while half-way up the slope a low density concentration of MP quartz artifacts was identified and collected.

\section{Raw Materials and Technology}

\section{Al Qana-1}

All of the MP material at QAN-1 is made of rhyolite, mostly having a blue color with many phenocrysts, but with some variation in color and texture. A rhyolite dyke associated with lithics was identified nearby on the edge of Al Qana village, demonstrating that rhyolite was available locally. It is generally not possible to determine the original clast form of the lithics at QAN-1, but where it can be observed, both cobbles and large flakes are represented. There was no evidence at QAN-1 that lithic material had been transported down-fan by higher energy transport-deposition mechanisms such as channel or cohesive debris flows. Rather the raw material was brought to the alluvial surface by hominins and knapped on site.

The QAN-1 assemblage (FIG. 6) is of considerable interest for several reasons. In particular, it is the first rhyolite assemblage analyzed in detail from Saudi Arabia, and from all of Arabia aside from the Late MP localities in Wadi Surdud, Yemen, where rhyolite is also the most common raw material (Delagnes et al. 2012, 2013). Furthermore, aside from the Yemeni site of SD2, QAN-1 is the first reported assemblage to be dominated by discoidal reduction in Arabia, and it is the first in Saudi Arabia. Many Arabian MP assemblages contain discoidal cores, but usually in the context of Levallois dominated assemblages (for example, Wahida et al. 2009). The definition of discoidal reduction used here follows that of Boëda (1993, 1995; Peresani 2003). QAN-1 is the densest lithic scatter described here. The total number of lithics across the site numbers in the thousands.

\footnotetext{
*figure 6 hereabouts*
} 
A sample of 40 cores was collected from QAN-1, focused on the two concentrations described above. A total of $75 \%$ of these cores (FIG. 6B, C) are classically discoidal. A further $10 \%$ are of discoidal character, but have a slight hierarchical relationship between the faces of the core. A further $11 \%$ have a pronounced hierarchical relationship between faces (e.g. FIG. 6A, D), where one surface of the core is more platform-like and the other is the primary debitage surface. In this volumetric structure these cores are broadly Levallois-like. Most of the QAN-1 cores are of a fairly similar size; approximately 50-70 $\mathrm{mm}$ in length and 50-70 mm in width, while thickness is more varied.

Clearly, core reduction at QAN-1 was dominated by the discoidal method, but with some Levallois characteristics. In at least one case (FIG. 6A), it appears that the "Levallois" surface was the ventral surface of a large overshot flake from a discoidal core. These very thick flakes (FIG. 6H) remove an entire face of a discoidal core, and produce a flake of essentially the morphology of a Levallois core "preform." From this we can see that Levallois-like flaking (in a volumetric sense) occurred within an essentially discoidal reduction sequence. Here we follow the descriptions of discoidal technology made by scholars such as Terradas (2003), which emphasize that many of the individual traits associated with discoidal reduction are also associated with other reduction methods. Features such as the angle of removals distinguish between idealized Levallois and discoidal forms, but in reality many examples fall between these poles. Core reduction at QAN-1 was discoidal in terms of volumetric aspects, such as a general lack of distinction between platform and debitage surfaces, as well as lacking the distinction between "predetermining" and "predetermined" flakes (contra Levallois). For us the occasional "Levallois-like" features occur within the range of variability of the discoidal method.

The characteristics of the debitage are congruent with those of the cores, and what one would expect of discoidal reduction. Flakes of various sizes are present, from small chips and 
flakes to large flakes up to $90 \mathrm{~mm}$ in length. The striking platforms are usually thick. Most flakes do not have prominent bulbs of percussion, but many have pronounced eraillure scars. A few of the flakes have faceted platforms, but most are plain.

Three major kinds of flakes can be described at QAN-1. Firstly, there are small flakes, usually around 10-40 $\mathrm{mm}$ in length and width and $\sim 10 \mathrm{~mm}$ thick. Secondly, there are thick flakes, which seem to represent overshot discoidal flakes (FIG. 6H). Finally, there are relatively thin and often rather elongate ( $\sim 80 \mathrm{~mm}$ long and $50 \mathrm{~mm}$ wide) flakes which are consistent with being produced by the discoidal method. There is not much consistency in the size and shape of striking platforms on these flakes; some are highly flattened (i.e. thin and wide), while others are thick and narrow. They generally have around 4 to 6 scars on their dorsal surfaces. Few retouched flakes were identified at QAN-1. Of those located, retouch is generally unsystematic, and was applied to both the lateral (FIG. 6G) and distal margins of flakes.

\section{Shuwaymis-11}

The lithic assemblage at SHW-11 consists of a high-density scatter of lithics on a flat area beside a river channel. The total number of lithics is difficult to determine, but probably numbers in the thousands. The lithics are all made of moderately fine-grained igneous raw material of rhyolitic character, which is orange/brown colored and has small phenocryts. This rhyolite was preferentially chosen from large river gravels which also include basalts. The raw material used seems to have come in the form of cortical nodules, rounded by the fluvial action of the adjacent river. By contrast, most of the rock in the surrounding landscape consists of poor-quality basalt. The rhyolite cobbles were used by MP hominins to produce lithics on site. 
All lithics at SHW-11 are of MP character. Much of the assemblage consists of amorphous flakes and chunks. The cores are virtually all of Levallois type, with exceptions being either at an early stage of reduction or of simple character. Given the dominance of centripetal preparation, we hypothesize that Levallois cores at SHW-11 were prepared centripetally, and then exploited either unidirectionally (FIG. 7 A, B) or bidirectionally (FIG. 7 C). Refitting is required to test this hypothesis. Recurrent centripetal and Nubian methods do not appear to be present at the site. Striking platforms on the Levallois cores were faceted, but not in a particularly fine fashion.

*figure 7 hereabouts*

The debitage includes few predetermined flakes, which the predetermining scar patterns on the cores clearly show were produced on the site. These must have then been transported into the wider landscape. This indicates that SHW-11 primarily functioned as a raw material procurement and initial reduction locality. The debitage is rather diverse in terms of size and shape, while tending towards being rather small. Very few retouched forms are present, and those identified have simple side retouched lateral margins.

\section{Dawadmi-23}

DWD-23 produced a low density assemblage (at most a few hundred) of MP artifacts close to a dyke of fine grained igneous raw material, described by the geological map as being microgranite (Delfour et al. 1984). This appears to be a fairly good raw material for knapping, both in terms of the quality and homogeneity of the raw material, but also in terms of shape. In many cases the clasts had natural convexities which were supplemented by preparatory flaking (e.g. the right margins)(FIG. 8A, F). While a small assemblage, the DWD-23 material has a diversity of forms of cores and flakes. 
A sample of nine cores was collected for analysis. These can be divided into four categories. Two are early stage cores, probably Levallois preforms. Two are centripetally prepared and bidirectionally exploited Levallois cores (FIG. 8B, C) one producing at least one elongated pointed flake (FIG. 8C). Two were centripetally prepared preferential Levallois cores. A further two are centripetally prepared, with steep preparatory scars, and have two Levallois removals on their upper surfaces, both struck from the same ends of the cores (FIG. 8A). The final core (FIG. 8D) has an interesting set of characteristics. Strictly speaking, it cannot be described as a Levallois core, as it lacks opposing, hierarchically related surfaces. Convexity was formed by steeply angled preparatory removals from a flat lower surface. A triangular flake was struck from a faceted striking platform. In some regards the core resembles Nubian Levallois cores, in that several removals converge on a median distal ridge, which has resulted in the pointed shape of the preferential removal.

From this collection of cores it is clear that a range of technological approaches was being employed at DWD-23, with both pointed and oval flakes being produced by different debitage methods. The extent to which this diversity points to the nature of the site as a palimpsest is currently unclear. If relatively limited, this diversity may reflect the seemingly fairly high quality, but quite unusual (microgranite), raw material, and the size and shape of the clasts. It is clear that in some cases, the character of core reduction was influenced by the morphology of the raw material clasts.

*figure 8 hereabouts*

Flakes at the site share the diversity of the cores. They are of various sizes, and feature unidirectional, bidirectional and centripetal scar patterns. They mostly have plain striking platforms. Two examples of flakes from DWD-23 are shown in figure 8 (E, F). Both are generally pointed flakes. One is Levallois-like, and has a bidirectional scar pattern. The other 
is of laminar proportions, and appears to be a débordant flake struck along the lateral margin of the core. Both have plain striking platforms. A few flakes at the site are retouched on the lateral (e.g. FIG. 8F) and distal margins, but in most cases this retouch appears less weathered than the rest of the material, and so may represent more recent reuse.

\section{Az Zu'aynah-2}

The lithics from AZA-2 come from localized scatters of low/medium density along a short stretch of river margin. There is, therefore, not a large sample size from the locality, probably a few hundred on the surface in total, but as with the other sites there is enough to describe the basic morpho-technological characteristics of the assemblage. Most of the lithics are made of a fine grained igneous raw material, with a single example of rhyolite.

The cores are all of Levallois type, with seven recurrent centripetal forms and one preferential with centripetal preparation. These cores vary in size from $145 \times 115 \times 50 \mathrm{~mm}$ in size down to $55 \times 35 \times 15 \mathrm{~mm}$. The cores display various phases of reduction intensity, so the reduction method employed here, primarily recurrent centripetal Levallois, does not seem to represent a phase of reduction or a way to reduce particular forms of raw material. Striking platforms on all cores are faceted, to varying degrees. They produced relatively large numbers of flakes. The cores represent classic examples of the recurrent centripetal Levallois technique (Hovers 2009).

\section{*figure 9 hereabouts*}

In contrast to the highly organized and formal core technology, the flake assemblage is highly variable and not standardized. Most of the flakes are relatively large and variously shaped, perhaps reflecting the initial stages of reduction and the basic shaping of the core. They mostly have plain platforms and unidirectional or centripetal scar patterns. Some examples have cortex. Others, such as those shown in Figure $9(\mathrm{C}-\mathrm{E})$, demonstrate Levallois 
characteristics. They have faceted striking platforms and dorsal scar patterns (centripetal and "crossed") showing Levallois convexity management. These flake forms are congruent with recurrent centripetal Levallois reduction. Only one retouched flake was identified, and as with DWD-23 this appears to have been resharpened in more recent times, as the retouched portion is much less weathered than the rest of the piece.

\section{Jebel Abyad-1}

The MP material at ABY-1 is present in small numbers, although a vast amount of quartz is present at the site and it is difficult to distinguish lithics from natural quartz without careful examination. ABY-1 highlights the diversity of raw materials used by MP knappers in the of the Nejd.

*figure 10 hereabouts*

Again our analysis focused on the cores, due to the ease with which these could be identified. The knapped pieces are difficult to read, as is often the case with quartz, with flakes often being removed along natural planes in the material as much as fracturing conchoidally. Most of the cores are Levallois (FIG. 10A, C), with two discoidal cores also recognized (FIG. 10B). The Levallois cores have facetted platforms and may be classed as preferential forms.

No definite Levallois flakes were noted at the site, with most flakes being either small and amorphous or larger and often with some cortex (FIG. 10D, E). The flakes shown in Figure 10, however, do have some broadly Levallois-like characteristics, i.e. faceted platforms and lateral and distal convexities imposed by centripetal flaking. They are, however, rather large and thick, which may reflect the characteristics of the raw material. These flakes also have cortex at their distal ends. Distal convexity is produced by the natural shape of the clast rather than by flaking (see also Kuhn 1995). 


\section{Discussion and Conclusions}

Fieldwork in the Nejd region of Saudi Arabia has revealed a rich MP record. The newly identified sites reported here are located in different positions in the landscape: in proximity to palaeolakes (Jubbah), in association with fluvial channels and sediments (SHW-11, QAN1, AZA-2) and at raw material sources (e.g., DWD-23, ABY-1).

The multitude of raw materials used contrasts with many areas where the majority of sites are focused on a single raw material (e.g., chert in the Levant and Dhofar). Raw materials in the Nejd and southern Nefud include various forms of igneous rock, generally of fairly fine grained composition, including microgranite at DWD-23. Rhyolite is another material often used by the MP knappers of the Nejd. The surveys reported here have not found clear evidence for the use of coarse grained igneous raw material such as andesite, but Zarins and colleagues (1980) state that they did. In contrast, there is abundant evidence of andesite being used by LP hominins (Jennings et al. 2015 b). Quartz was often used in the MP, both in the form of rounded pebbles (e.g., at JKF-1 at Jubbah) and angular clasts from quartz veins (ABY-1). Quartzite was the main raw material used at Jubbah and elsewhere (e.g., at AK-22). Finally, chert occurs in variable frequencies. This considerable diversity of raw materials has to be factored into lithic technology comparisons, alongside other explanations of variability. In most cases, MP sites are located near raw material sources, leading to assemblage characteristics such as generally low reduction intensity and a paucity of retouch.

A wide range of core reduction methods are likewise found at these sites. Given the lack of chronometric age estimates it is difficult to interpret any spatial and temporal patterns. Here we have described the first assemblage from Saudi Arabia to be dominated by discoidal reduction (QAN-1). Most of the assemblages identified focused on various forms of Levallois 
technology: preferential Levallois with centripetal preparation (e.g., at SHW-11 and ABY-1), recurrent centripetal Levallois (JQ-1 at Jubbah, AZA-2 and unidirectional-convergent Levallois (JKF-1 at Jubbah). These variations do not appear to simply correspond with raw material forms, and at least a large part of the variability seen can be hypothesized to represent cultural (learned) behaviors of different populations. Such interpretations, however, need to be considered alongside more pragmatic factors such as variable reduction intensity. It is also possible that particular reduction methods were reinvented multiple times in the Pleistocene world. This is in fact likely, given the size and environmental complexity of the Arabian Peninsula, and the temporal range of dated Middle Palaeolithic sites.

The current study, therefore, emphasizes the variability of the MP of the Nejd. This diversity takes the form of the positions of sites in the landscape, of the raw materials used for lithic reduction, and of the core reduction methods. The technological diversity probably has several explanations, including the limitations of particular raw material types and variable environmental conditions through time, but also reflects different populations using the landscape in different ways through time. Along with discoidal and other methods, most forms of Levallois reduction have been identified. In a broad sense, the dominance of the centripetal Levallois method is similar to that documented in MIS 5 Levantine assemblages and many in eastern, and some northeastern, African assemblages (Groucutt et al. 2015 b). Whereas some assemblages in the Nefud desert feature the unidirectional-convergent Levallois method (Groucutt et al. 2015 a), this technology, common in the Levantine Late MP (Henry 2003; Groucutt 2014) appears to be rare in the Nejd area. While some central Arabian assemblages contain Nubian (beaked) Levallois cores, these generally seem to be in small numbers (Crassard and Hilbert 2013), and therefore different from the assemblages of Dhofar (where Nubian Levallois cores can constitute as much as $90 \%$ of the cores)(Usik et al. 2013). Our surveys found only occasional evidence for Nubian Levallois-like cores. We did 
not find any evidence in support of the idea that the Levantine Upper Palaeolithic stemmed from a northwards movement of populations through Arabia (Marks and Rose 2014). Clearly, though, all hypotheses must be tempered by the possibility, if not probability, of future discoveries in the Nejd area that may radically alter our understanding. Given the dominant aridity of Arabia it seems parsimonious that the assemblages we have documented probably date to interglacial periods such as MIS 5, but the temporal variation of the findings is currently unclear.

While few areas of the Arabian Peninsula are known in detail, the emerging picture of MP technological heterogeneity in Saudi Arabia can be contrasted to areas described as being more technologically homogenous such as Dhofar (Rose et al. 2011; Usik et al. 2013) and the Huqf (Jagher 2009) in Oman. One interpretation of this is that populations repeatedly dispersed into Arabia, before environmental deterioration left them isolated in refugial areas of southern and eastern Arabia (Delagnes et al. 2012, 2013). The reduction in population sizes and connectivity can be hypothesized to have led to a loss of technological diversity and therefore to more homogenous reduction methods and toolkits. Such hypotheses of course require testing from further excavated and dated sites, particularly in the interior of Arabia and, where possible, in direct association with records of environmental change. Given the small number of excavated sites, and the even smaller number with reliable absolute age estimates, caution is needed in inferring specific connections with neighboring regions until the spatial and temporal parameters of variability are better understood in the Arabian Peninsula. It is also imperative that archaeologists in Arabia develop an understanding of factors such as tool use and mobility strategies, rather than simply connecting Arabian sites to poorly defined industries from surrounding regions.

\section{Acknowledgments}


We thank HRH Prince Sultan bin Salman bin Abdulaziz Al-Saud, President of the Saudi Commission for Tourism and Antiquities (SCTA), and Professor Ali Ghabban, Vice President of the SCTA for permission to carry out this study. The research was funded by the European Research Council (no. 295719, to MDP). Breeze was funded by NERC studentship NE/J500306/1.

Huw S. Groucutt (Ph.D. 2013, University of Oxford) is a British Academy postdoctoral research fellow at the School of Archaeology, University of Oxford with a research interest in the Middle Palaeolithic of the Saharo-Arabian area and its implications for hominin dispersal and adaptation.

Paul Breeze (M.A. 2007, University of Birmingham) is a Ph.D. student in the department of Geography at King's College London, with research interests in using GIS and remotely sensed data to identify and characterize archaeological sites, and to examine potential relationships between Arabian palaeohydrology and hominin dispersals.

Nick A. Drake (Ph.D. 1992, University of Reading) is a professor in Physical Geography at the Department of Geography, King's College, London with research interests in the palaeoclimate and geoarchaeology of semi-arid and arid regions and the role of the SaharaArabian deserts in human evolution and "out of Africa" dispersals.

Richard Jennings (Ph.D. 2007, University of Oxford) is a postdoctoral researcher specializing in archaeological surveying, mapping and excavation of Palaeolithic archaeological sites in the Arabian Peninsula and the western Mediterranean.

Ash Parton (Ph.D. 2013, Oxford Brookes University) is a lecturer at the University of Oxford and Oxford Brookes University addressing palaeoclimatic and palaeoenvironmental changes in Arabia throughout the Late Quaternary. 
Tom S. White (Ph.D. 2012, University of Cambridge) is a postdoctoral researcher at the University of Oxford with a research interest in Quaternary paleaoecology, particularly nonmarine molluscs and ostracods, and their application to reconstructions of past climates and environments.

Ceri Shipton (Ph.D. 2008, University of Cambridge) is a postdoctoral research fellow in the McDonald Institute, University of Cambridge. His research interests include the dispersal of Homo sapiens, lithic technology, the prehistory of Arabia, and the fate of the Neanderthals.

Laine Clark-Balzan (Ph.D. 2013, University of Oxford) is a postdoctoral researcher at the University Freiberg, whose interests focus on conducting applied and experimental research in OSL dating.

Abdulaziz al-Omari (B.A. 1985, King Saud University) works at the Saudi Commission for Tourism and Antiquities in Riyadh and works on a variety of survey and excavation projects in Saudi Arabia.

Patrick Cuthbertson (MSt. 2013, University of Oxford) is a graduate reading for the Ph.D. in archaeology at the University of Oxford. His research interests focus on lithic analysis and hominin adaptation in the landscape.

Oshan Manjula Chanaka Wedage (M.A. 2011, Deccan College, India) is a researcher at the Department of Archaeological Survey of Sri Lanka and is currently the Project Officer for excavations at the Pahiyangal Cave in Sri Lanka.

Marco A. Bernal (M.A. 2012, University Rovira $i$ Virgili [Tarragona, Spain] and the National Museum of Natural History [Paris, France]) is currently a Talentia Scholarship Ph.D. candidate at the University of Oxford with a research interest in the Middle Palaeolithic of Eurasia and its implications for hominin dispersal and adaptive cultural behavior. 
Abdullah Alsharekh (Ph.D. 1996, University of Cambridge) is an associate professor at King Saud University, Riyadh, Saudi Arabia. His work focuses on the prehistoric archaeology of Saudi Arabia.

Michael D. Petraglia (Ph.D. 1987, University of New Mexico) is Professor of Human Evolution and Prehistory, Senior Research Fellow and the Co-Director of the Centre for Asian Archaeology, Art and Culture at the School of Archaeology, University of Oxford. He is also a Senior Research Fellow, Linacre College (Oxford) and a member of the Human Origins Program, Smithsonian Institution, Washington, D.C.

\section{References}

Armitage, S. J., S. A Jasim, A. E. Marks, A. G. Parker, V. I. Usik, and H. P. Uerpmann. 2011. "The Southern Route 'out of Africa': Evidence for an Early Expansion of Modern Humans into Arabia," Science 331: 453-456.

Boëda, E. 1993. “Le débitage discoïde et le débitage Levallois recurrent centripète,” Bulletin de la Société Préhistorique Française 90: 392-404.

Boëda, E. 1995. “Levallois: A Volumetric Construction, Methods, and Technique," in H. L. Dibble and O. Bar-Yosef, eds., The Definition and Interpretation of Levallois technology. Ann Arbor: Prehistory Press, 41-68.

Breeze, P., N. A. Drake, R. G. Jennings, A. Parton, H. S. Groucutt, L. Clark-Balzan, C. Shipton, T. White, M. D. Petraglia, and A. Alsharekh. 2015. "Remote Sensing and GIS 
Techniques for Reconstructing Arabian Paleohydrology and Identifying Archaeological Sites," Quaternary International 382, 98-119.

Bretzke, K., N. J. Conard, and H. P. Uerpmann. 2014. "Excavations at Jebel Faya-the FAYNE1 Shelter Sequence, Proceedings of the Seminar for Arabian Studies 44: 69-82.

Crassard, R., and Y. H. Hilbert. 2013. "A Nubian Complex Site from Central Saudi Arabia: Implications for Taxonomy and Human Dispersals During the Upper Pleistocene," PLoS ONE 8: e69221.

Crassard, R., M. D. Petraglia, N. Drake, P. Breeze, B. Gratuze, A. Alsharekh, M. Arbach, H. S. Groucutt, L. Khalidi, N. Michelsen, C. J. Robin, and J. Schietteccate. 2013a. "Middle Palaeolithic and Neolithic Occupations Around Mundafan Palaeolake, Saudi Arabia: Implications for Climate Change and Human Dispersals," PLoS ONE 8: e69665.

Crassard, R., M. D. Petraglia, A. G Parker, A. Parton, R. G. Roberts, Z. Jacobs, A. Alsharekh, A. Al-Omari, P. Breeze, N. A Drake, H. S. Groucutt, R. Jennings, E. Régagnon, and C. Shipton. 2013b. "Beyond the Levant: First Evidence of a Pre-Pottery Neolithic Incursion into the Nefud Desert, Saudi Arabia," PLoS ONE 8: e68061.

Delagnes, A., R. Crassard, P. Bertran, and L. Sitzia. 2013. "Cultural and Human Dynamics in Southern Arabia at the End of the Middle Paleolithic," Quaternary International 300: 234243.

Delagnes, A., C. Tribolo, P. Bertran, M. Brenet, R. Crassard, J. Jaubert, L. Khalidi, N. Mercier, S. Nomade, S. Peigne, L. Sitzia, J. F. Tournepiche, M. Al-Halibi, A. Al-Mosabi, and R. Macciarelli. 2012. "Inland Human Settlement in Southern Arabia 55,000 Years Ago. New Evidence from the Wadi Surdud Middle Paleolithic Site Complex, Western Yemen,” Journal of Human Evolution 63: 452-474. 
Delfour, J., R. Dhellemmes, P. Elass, D. Vaslet, J. M. Brosse, Y. M. Le Nindre, and O.

Dottin. 1984. Geologic Map of the Ad Dawadmi Quadrangle. Sheet 24G. Jiddah: Ministry of Petroleum and Mineral Resources.

Garrard, A. N., C. P. D. Harvey, and V. R. Switsur. 1981. "Environment and Settlement During the Upper Pleistocene and Holocene at Jubba in the Great Nefud, Northern Arabia," Atlal 5: 137-148.

Ghoneim, E., and F. El-Baz. 2007a. "The Application of Radar Topographic Data to Mapping of a Mega-paleodrainage in the Eastern Sahara," Journal of Arid Environments 69: 658-675.

Ghoneim, E., and F. El-Baz. 2007b. "DEM-optical-radar Data Integration for Palaeohydrological Mapping in the Northern Darfur, Sudan: Implications for Groundwater Exploration,” International Journal of Remote Sensing 28: 5001-5018.

Groucutt, H. S., 2014. "Middle Palaeolithic Point Technology, With a focus on The Site of Tor Faraj (Jordan, MIS 3)," Quaternary International 350: 205-226.

Groucutt, H. S., and J. Blinkhorn. 2013. "The Middle Palaeolithic in the Desert and Its Implications for Understanding Hominin Adaptation and Dispersal," Quaternary International 300: 1-12.

Groucutt, H. S. and M. D. Petraglia. 2012. "The Prehistory of Arabia: Deserts, Dispersals and Demography," Evolutionary Anthropology 21: 113-125.

Groucutt, H. S., and M. D. Petraglia. 2014. “An Arabian Perspective on the Dispersal of Homo sapiens out of Africa," in R. Dennell and M. Porr, eds., Southern Asia, Australasia and Human Origins. Cambridge: Cambridge University Press, 51-63. 
Groucutt, H. S., M. D. Petraglia, G. Bailey, E. M. L. Scerri, A. Parton, L. Clark-Balzan, R. P. Jennnigs, L. Lewis, J. Blinkhorn, N. A. Drake, P. S. Breeze, R. H. Inglis, M. H. Devès, M. Meredith-Williams, N. Boivin, M. G. Thomas, and A. Scally. 2015 c. "Rethinking the dispersal of Homo sapiens out of Africa." Evolutionary Anthropology 24, 149-164.

Groucutt, H. S., E. M. L. Scerri., L. Lewis, L. Clark-Balzan, J. Blinkhorn, R. P. Jennings, A. Parton, and M. D. Petraglia. 2015 b. "Stone tool assemblages and models for the dispersal of Homo sapiens out of Africa". Quaternary International 382, 8-30.

Groucutt, H. S., C. Shipton, A. Alsharekh, R. Jennings, E. M. L. Scerri, and M. D. Petraglia. 2015 a. "Late Pleistocene Lakeshore Settlement in Northern Arabia: Middle Palaeolithic Technology from Jebel Katefeh, Jubbah.” Quaternary International 382, 215-236.

Henry, D. O. 2003. Neanderthals in the Levant. Behavioral Organization and the Beginnings of Human Modernity. London: Continuum.

Hovers, E. 2009. The Lithic Assemblage of Qafzeh Cave. New York: Oxford University Press.

Jagher, R. 2009. “The Central Oman Paleolithic Survey: Recent Research in Southern Arabia and Reflection on the Prehistoric Evidence," in M. D. Petraglia and J. I. Rose, eds., The Evolution of Human Populations in Arabia. Dordrecht, Heidelberg, London, New York: Springer, 139-150.

Jagher, R., C. Pümpin, F. Egmüller, and I. Winet. 2011. “Central Oman Palaeolithic Survey Report, 2007 Season,” Journal of Oman Studies 17: 15-50.

Jennings, R. P., C. Shipton, P. Breeze, P. Cuthbertson, M. A. Bernal, W. M. C. Oshan Wedage, N. A. Drake, T. S. White, H. S. Groucutt, A. Parton, L. Clark-Balzan, C. Stimpson, A. Al Omari, A. Alsharekh, and M. D. Petraglia. 2015 b. Multi-scale Acheulean Landscape Survey in the Arabian Desert. Quaternary International 382, 58-81. 
Jennings, R. P., J. Singarayer, E. Stone, U. Krebs-Kanzow, V. Khon, K. H. Nisancioglu, A. G. Parker, A. Parton, H. S. Groucutt, T. White, N. A. Drake, and M. D. Petraglia. 2015 a. "The Greening of Arabia: Multiple Opportunities for Human Occupation of the Arabian Peninsula During the Late Pleistocene Inferred from an Ensemble of Climate Model Simulations.” Quaternary International 382, 181-199.

Kuhn, S. L. 1995. Mousterian Lithic Technology: An Ecological Perspective. Chicago: Chicago University Press.

Lehner, B., K. Verdin, and A. Jarvis. 2008. "New Global Hydrography Derived from Spaceborne Elevation Data," EOS, Transactions of the American Geophysical Union 89: 9394.

Marks, A. E., and J. I. Rose. 2014. “Through A Prism of Paradigms: A Century of Research Into The Origins of the Upper Palaeolithic in the Levant.” in M. Otte, ed., Néandertal/Cro Magnon. Le recontre. Liege: ERAUL, 63-93.

Mellars, P., K. C. Gori, M. Carr, P. A. Soares, P. A., and M. B. Richards. 2013. "Genetic and Archaeological Perspectives on the Initial Modern Human Colonization of Southern Asia," Proceedings of the National Academy of Sciences USA 110: 10699-10704.

Parr, P. J., J. Zarins, M. Ibrahim, J. Waechter, A. Garrard, C. Clarke, M. Bidmead, and H. Al Badr. 1978. "Preliminary Report on the Second Phase of the Northern Province Survey 1397/1977," Atlal 2: 29-50.

Parton, A., T. S. White, A. G. Parker., P. S. Breeze, R. Jennings, H. S. Groucutt, and M. D. Petraglia. 2015. “Orbital-scale Climate Variability in Arabia as a Potential motor for Human Dispersals." Quaternary International 382, 82-97. 
Peresani, M. 2003. Discoid Lithic Technology: Advances and Implications. BAR International Series 1120. Oxford: Archaeopress.

Petraglia, M. D., and A. Alsharekh. 2003. "The Middle Palaeolithic of Arabia: Implications for Modern Human origins, Behaviour and Dispersals," Antiquity 77: 671-684.

Petraglia, M. D., A. Alsharekh, P. Breeze, C. Clarkson, R. Crassard, N. A. Drake, H. S.

Groucutt, R. Jennings, A. G. Parker, A. Parton, R. G. Roberts, C. Shipton, C. Matheson, A. alOmari, and M.-G. Veall. 2012. "Hominin Dispersal Into the Nefud Desert and Middle Palaeolithic Settlement Along the Jubbah Palaeolake, Northern Arabia," PLoS ONE 7(11): e49840.

Petraglia, M. D., A. Alsharekh, R. Crassard, N. A. Drake, H. S. Groucutt, A. G. Parker, and R. G. Roberts. 2011. "Middle Paleolithic Occupation of a Marine Isotope Stage 5 Lakeshore in the Nefud Desert, Saudi Arabia," Quaternary Science Reviews 30: 1555-1559.

Petraglia, M. D., N. Drake, and A. Alsharekh. 2009. “Acheulean Landscapes and Large Cutting Tool Assemblages in the Arabian Peninsula," in M. D. Petraglia and J. I. Rose, eds., The Evolution of Human Populations in Arabia. Dordrecht, Heidelberg, London, New York: Springer, 103-116.

Petraglia, M. D., and J. I. Rose. 2009. The Evolution of Human Populations in Arabia. Dordrecht, Heidelberg, London, New York: Springer.

Roobol, M. J., and V. E. Camp. 1991. Geologic Map of the Cenozoic Lava Fields of Harrats Khaybar, Ithnayn, and Kura. Jeddah: Ministry of Petroleum and Mineral Resources.

Rose, J. I., V. I. Usik, A. E. Marks, Y. H. Hilbert, C. S. Galleti, A. Parton, J. M. Geiling, V. Černý, M. W. Morley, and R. G. Roberts. 2011. “The Nubian Complex of Dhofar, Oman: An African Middle Stone Age Industry in Southern Arabia," PLoS ONE 6: e28239. 
Scerri, E. M. L., S. P. Breeze, A. Parton, H. S. Groucutt, T. S. White, C. Stimpson, L. ClarkBalzan, R. Jennings, A. Alsharekh, and M. D. Petraglia. 2015. "Middle to Late Pleistocene Human Habitation in the Western Nefud Desert, Saudi Arabia." Quaternary International $382,200-214$.

Scerri, E. M. L., H. S. Groucutt, R. P. Jennings, and M.D. Petraglia. 2014. "Unexpected Technological Heterogeneity in Northern Arabia Indicates Complex Late Pleistocene Demography at the Gateway to Asia." Journal of Human Evolution 75: 125-42.

Schiettecatte, J., A. Al-Ghazi, G. Charlous, R. Crasard, Y. H. Hibert, H. Monchot, M. Mouton, and P. Siméon. 2013. "The Oasis of Al-Kharj Through Time: First Results of Archaeological Fieldwork in the Province of Riyadh (Saudi Arabia)," Proceedings of the Seminar for Arabian Studies 43: 285-308.

Shipton, C., A. Parton, P. Breeze, R. Jennings, H. S. Groucutt, T. S. White, N. Drake, R. Crassard, A. Alsharekh, and M. D. Petraglia. 2014. "Large flake Acheulean in the Nefud Desert of Northern Arabia," Paleoanthropology 2014: 446-462.

Terradas, X. 2003. "Discoid Flaking Method: Conception and Technological Variability," in M. Peresani, ed., Discoid Lithic Technology: Advances and Implications. Oxford: Archaeopress, 19-31.

Thompson, J. C., A. Mackay, V. de Moor, and E. Gomani-Chindebvu. 2014. "Catchment Survey in the Karonga District: A Landscape-scale Analysis of Provisioning and Core Reduction Strategies During the Middle Stone Age of Northern Malawi." African Archaeological Review 31: 447-478.

Usik, V. I., J. I. Rose, Y. H Hilbert, P. Van Peer, and A.E. Marks. 2013. "Nubian Complex Reduction Strategies in Dhofar, Southern Oman," Quaternary International 300: 244-266. 
Wahida, G., W. Y. Al-Tikriti, and M. J. Beech. 2009. “Acheulean Landscapes and Large

Cutting Tool Assemblages in the Arabian Peninsula,” In M. D. Petraglia and J. I. Rose, eds., The Evolution of Human Populations in Arabia. Netherlands: Springer, 117-124.

Zarins, J., M. Ibrahim, D. Potts, and C. Edens. 1979. "The Preliminary Report on the Third Phase of the Comprehensive Archaeological Survey Program - The Central Province," Atlal 3: $9-42$.

Zarins, J., A. A. Rahbini, and M. Kamal. 1982. "Preliminary Report on the Archaeological Survey of the Riyadh Area," Atlal 6: 25-38.

Zarins, J., N. Whalen, M. Ibrahim, A. A. Jawad Mursi, and M. Kahn. 1980. “Comprehensive Archaeological Survey Program, Preliminary Report on the Central and Southwestern Provinces survey, 1979," Atlal 4: 9-36.

\section{Tables}

Table 1. Newly discovered Middle Palaeolithic sites in central and northern Saudi Arabia.

\begin{tabular}{|c|c|c|c|c|c|}
\hline Site & $\begin{array}{l}\text { Latitude/ } \\
\text { longitude }\end{array}$ & Site context & $\begin{array}{l}\text { Raw } \\
\text { materials }\end{array}$ & $\begin{array}{l}\text { Lithic } \\
\text { density }\end{array}$ & $\begin{array}{l}\text { Dominant reduction } \\
\text { methods }\end{array}$ \\
\hline $\begin{array}{l}\text { Al Qana-1 } \\
\text { (QAN-1) }\end{array}$ & $\begin{array}{l}27.7665 \\
41.4119\end{array}$ & $\begin{array}{l}\text { Distal } \\
\text { alluvial fan } \\
\text { surface }\end{array}$ & Rhyolite & High & $\begin{array}{l}\text { Discoidal, small presence } \\
\text { of Levallois }\end{array}$ \\
\hline $\begin{array}{l}\text { Shuwaymis- } \\
11 \text { (SHW- } \\
\text { 11) }\end{array}$ & $\begin{array}{l}26.1235 \\
40.3834\end{array}$ & $\begin{array}{l}\text { Beside river } \\
\text { channel }\end{array}$ & Rhyolite & High & $\begin{array}{l}\text { Levallois, unidirectional } \\
\text { and bidirectional } \\
\text { exploitation with } \\
\text { centripetal preparation }\end{array}$ \\
\hline $\begin{array}{l}\text { Az } \\
\text { Zu'aynah-2 } \\
\text { (AZA-2) }\end{array}$ & $\begin{array}{l}24.3506 \\
44.9915\end{array}$ & $\begin{array}{l}\text { Beside river } \\
\text { channel }\end{array}$ & $\begin{array}{l}\text { Fine grained } \\
\text { igneous }(+1 \\
\text { rhyolite) }\end{array}$ & Medium & $\begin{array}{l}\text { Recurrent centripetal } \\
\text { Levallois }\end{array}$ \\
\hline $\begin{array}{l}\text { Dawadmi- } \\
23 \text { (DWD- } \\
\text { 23) }\end{array}$ & $\begin{array}{l}24.8956 \\
43.5408\end{array}$ & Below dyke & $\begin{array}{l}\text { Fine grained } \\
\text { igneous } \\
\text { (microgranite) }\end{array}$ & Low & $\begin{array}{l}\text { Diverse Levallois } \\
\text { methods }\end{array}$ \\
\hline
\end{tabular}




\begin{tabular}{|c|c|c|c|c|c|}
\hline $\begin{array}{l}\text { Jebel } \\
\text { Abyad-1 } \\
\text { (ABY-1) }\end{array}$ & $\begin{array}{l}24.2608 \\
44.4927\end{array}$ & Isolated hill & Quartz & Low & $\begin{array}{l}\text { Preferential Levallois } \\
\text { with centripetal } \\
\text { preparation, also discoidal }\end{array}$ \\
\hline
\end{tabular}

\section{Figure captions}

Figure 1. Middle Palaeolithic lithics from central and northern Saudi Arabia. A-D) JKF-1, Jubbah (Petraglia et al. 2012); A-C) quartzite Levallois points; D) quartz Levallois flake; EG) JSM-1, Jubbah, all siliceous quartzite (Petraglia et al. 2012); E, G) preferential Levallois cores with centripetal preparation; F) Levallois flake; H-J) JQ-1, Jubbah, all quartzite (Petraglia et al. 2011; 2012); H, J) side retouched flakes; I) recurrent centripetal Levallois core; K, L) AK-22, Al Kharj, both quartzite (Crassard and Hilbert, 2013); K) recurrent centripetal Levallois core; L) Nubian Levallois core.

Figure 2. Locations of newly discovered and previously published MP sites in the Arabian Peninsula., with palaeohydrology displayed (Breeze et al. 2015). Satellite imagery sources for 
this and subsequent figures: Esri, DigitalGlobe, GeoEye i-cubed, Earthstar Geographics, CNES/Airbus DS, USDA, USGS, AEX, Getmapping Aerogrid, IGP, swisstopo, and the GIS user community

Figure 3. Photos of newly discovered Middle Palaeolithic sites. A) test trench at QAN-1, dark blue items on surface are all MP quartzite lithics; B) View of SHW-11, located between lava flow (bottom left) and river channel (back right, lined by trees); C) Surface at SHW-11, the lighter colored objects are lithics; D) View of ABY-1 site, MP lithics are concentrated around lowest figure at center; E) AZA-2, river channel in foreground with sedimentary section at bottom left, lithic scatters along slope in background; F) DWD-23, a dense combination of natural and knapped stone beneath a dyke (back left).

Figure 4. Satellite imagery of QAN-1 (A) and SHW-11 (B), Hail province. QAN-1 is located on a patch of alluvial sediments, preserved between aeolian sand. SHW-11 is located beside a river channel in an area dominated by basaltic lava flows.

Figure 5. Satellite imagery of DWD-23 (A), ABY-1 (B) and AZA-2 (C), Dawadmi province. DWD-23 is located next to a dyke (microgranite), ABY-1 is situated on an isolated quartz eminence (note andesite dykes to both the north and south of the site) and AZA-2 is beside a fluvial channel.

\section{[Authors: Figure shows ABY-4, please correct]}

Figure 6. QAN-1 lithics, all rhyolite. A) Levallois-like discoidal core; B, C) Discoidal cores; D) Levallois-like discoidal core; E, F) Flakes; G) Side retouched flake; H) overshot discoidal flake.

Figure 7. SHW-11 lithics, all rhyolite. A, B) Preferential Levallois core with centripetal preparation' C) Bidirectional Levallois core with centripetal preparation. 
Figure 8. DWD-23 lithics, all micogranite. A) Preferential Levallois core with centripetal preparation; B, C) Bidirectional Levallois core with centripetal preparation; D) Core for a preferential flake, but non-Levallois volumetric configuration; E) Pointed flake with bidirectional scar pattern; F) Débordant-like flake.

Figure 9. AZA-2 lithics, all fine grained igneous raw material other than A (rhyolite). A, B) Recurrent centripetal Levallois cores; C-E) Levallois flakes.

Figure 10. ABY-1 lithics, all quartz. A, C) preferential Levallois core with centripetal preparation; B) Discoidal core; D, E) Thick flakes with faceted platforms, centripetal scar patterns and cortex at distal ends. 